International Journal of Child, Youth and Family Studies (2017) 8(3-4): 127-153

DOI: http://dx.doi.org/10.18357/ijcyfs83/4201718074

\title{
PREDICTING ADULTS' APPROVAL OF PHYSICAL PUNISHMENT FROM THEIR PERCEPTIONS OF THEIR CHILDHOOD EXPERIENCES
}

\author{
Joan E. Durrant, Elif Acar, Justin McNeil, Ailsa M. Watkinson, and Anne McGillivray
}

\begin{abstract}
Most physical violence against children in their homes is rooted in physical punishment. Parents' approval of physical punishment is a primary predictor of its use. Therefore, reducing approval of physical punishment is critical to preventing physical violence against children. We explored the relative contributions of four variables to young adults' approval of physical punishment with the aim of identifying effective routes to prevention. The participants were 480 first-year university students in 3 Canadian provinces. The outcome measure was a scale assessing participants' approval of physical punishment. The predictor variables were four dimensions of participants' perceptions of their childhood physical punishment experiences: physical (frequency, severity), cognitive (perceived abusiveness, perceived deservedness), affective (short- and long-term emotional impact), and contextual (degree to which it was accompanied by reasoning, power assertion, emotional abuse, or emotional support). Most (73\%) of the participants had experienced physical punishment in childhood. Of these, $78 \%$ had experienced punishments other than mild spanking with the hand; one fifth had been pushed against a wall, and one third had been hit with objects. The strongest predictor of participants' approval of physical punishment was a belief that their experiences were deserved. Reducing approval of physical punishment requires strategies to alter the perception that children deserve violence.
\end{abstract}

Keywords: physical punishment; attitudes; approval; physical abuse; prevention.

Joan E. Durrant $\mathrm{PhD}$ (the corresponding author) is a Professor in the Department of Community Health Sciences, University of Manitoba, Fort Garry Campus, 35 Chancellor's Circle, Winnipeg, MB R3T 2N2. Email: Joan.Durrant@UManitoba.ca

Elif Acar PhD is an Assistant Professor in the Department of Statistics, University of Manitoba, 318 Machray Hall, Winnipeg, MB R3T 2N2. Email: Elif.Acar@UManitoba.ca

Justin McNeil is a PhD candidate in Psychology at the University of Toronto, 100 St. George St., Toronto, ON M5S 3G3. Email: Justin.mcneil@mail.utoronto.ca

Ailsa M. Watkinson PhD is a Professor in the Faculty of Social Work, University of Regina, Saskatoon Campus, 111-116 Research Dr., Saskatoon, SK S7N 3R3. Email: Ailsa.Watkinson@uregina.ca

Anne McGillivray $\mathrm{PhD}$ is a Professor of Law (Retired), Faculty of Law, University of Manitoba, 224 Dysart Rd., Winnipeg, $\quad$ MB $\quad$ R3T 2 2. Email: Anne.McGillivray@umr.umanitoba.ca 
International Journal of Child, Youth and Family Studies (2017) 8(3-4): 127-153

The most common type of police-reported family violence against children in Canada is physical assault (Statistics Canada, 2015). The most recent Canadian incidence study of maltreatment reported to child welfare authorities revealed that more than 20,000 incidents of physical maltreatment were substantiated in 2008 (Public Health Agency of Canada, 2010). Between 2003 and 2013, 319 children in Canada were killed by a family member (Statistics Canada, 2015). Why is physical violence against children in the family still so prevalent in Canada? Since Dr. Henry Kempe identified the "battered child syndrome" (Kempe, Silverman, Stelle, Droegmueller, \& Silver, 1962), research has grown at an explosive pace, and prevention and treatment programs abound, yet the violence continues. What is missing from our efforts to end it?

The United Nations Global Study on Violence against Children called world attention to what may be the fundamental obstacle to child maltreatment prevention - the cultural legitimacy of violence against children (Pinheiro, 2006). The Study points specifically at the justification of physical punishment as a traditional value that stands in the way of eradicating physical violence against children. In every region of the world, ending social approval of physical punishment was identified by Study participants as fundamental to effective prevention efforts.

Evidence for this position has been accumulating for decades. From his examination of 1,380 cases of physical abuse, Gil (1970) concluded that the most common type "involves incidents developing out of disciplinary action taken by caretakers" (p. 126). His findings have been replicated repeatedly (Durrant et al., 2006; Kadushin \& Martin, 1981; Margolin, 1990; Trocmé, Siddiqi, Fallon, MacLaurin, \& Sullivan, 2002). Findings of the Canadian Incidence Studies of Reported Child Abuse and Neglect have repeatedly demonstrated that at least $75 \%$ of substantiated physical maltreatment takes place in a punitive context (Jud \& Trocmé, 2013; Trocmé et al., 2005; Trocmé et al., 2001). In a recent meta-analysis, physical punishment was strongly and consistently associated with indicators of physical abuse (Gershoff \& GroganKaylor, 2016). Children who are spanked are 7 times more likely to experience severe violence (Clément, Bouchard, Jetté, \& Laferrière, 2000). Infants who are spanked are 2.3 times more likely to sustain injuries requiring medical attention than those who are not spanked (Crandall, Chiu, \& Sheehan, 2006). Every occurrence of spanking increases the odds of physical abuse by 3\% (Zolotor, Theodore, Chang, Berkoff, \& Runyan, 2008). A Canadian study found that adults who reported having been spanked at age 10 were almost 60 times more likely to also report physically abusive experiences at that age (Fréchette, Zoratti, \& Romano, 2015).

These findings challenge the traditional notion that physical abuse is an act of violence while physical punishment is a legitimate parenting tool. In fact, some suggest that the perpetuation of this conceptual dichotomy affirms the legitimacy of violence against children (Belsky, 1980; Garbarino, 1977; Gelles \& Straus, 1988; McGillivray, 2011a). Increasingly, 
physical punishment is becoming recognized not only as unnecessary (Roberts \& Powers, 1990) and a developmental risk factor (Gershoff, 2013), but also as a violation of children's rights to physical security (Covell \& Howe, 2001, 2009; Gershoff \& Bitensky, 2007; Freeman \& Saunders, 2014; Watkinson, 1999). To date, 53 countries have explicitly prohibited physical punishment of children in all settings, including the home. ${ }^{1}$ These prohibitions affirm children's rights to physical security and are aimed at reducing the acceptability of physical punishment by delegitimizing it in the public mind (Durrant \& Janson, 2005; Smith \& Durrant, 2011).

In Canada, however, "punishment" is still distinguished from "abuse". In 2004, Canada's Supreme Court upheld the section of the Criminal Code that allows parental use of corrective force, but narrowed the definition of "reasonable" force to that applied with the hand with an impact that is "transitory and trifling" (for analyses of this ruling see McGillivray, 2011a, 2011b; McGillivray \& Durrant, 2012; McGillivray \& Milne, 2011; Watkinson, 2006, 2009). The Court assumed that it is the severity of physical punishment that is the fundamental issue in protecting children, failing to recognize that its implicit legitimization of physical punishment per se may be its most powerful message, perpetuating its perceived acceptability in the public mind (Durrant, Sigvaldason, \& Bednar, 2008; McGillivray, 2011b). The Court's decision highlighted a fundamental theoretical question: Will public approval of physical punishment be more effectively reduced by limiting its severity or by delegitimizing it altogether?

We explored this question through a survey of young adults (first-year university students) who had recently exited childhood and were approaching or entering parenthood. These individuals are still close to the experiences of their childhoods, and are likely to have adopted the social construction of physical punishment typical of their generation. Therefore, they provide an opportunity to examine the factors that influence their attitudes toward this practice in order to identify the most effective route to targeting and reducing its public approval.

\section{Approval of Physical Punishment}

Approval of physical punishment has been found to be a powerful predictor of its use more so than parental mood (Holden, Coleman, \& Schmidt, 1995), anger (Durrant, RoseKrasnor, \& Broberg, 2003; Socolar \& Stein, 1995) or childhood experience of physical punishment (Durrant et al., 2003). It was found to be the most powerful of eight predictors of mothers' use of physical punishment with their preschoolers (Ateah \& Durrant, 2005). A key belief among mothers at high risk for using physical punishment is that physical punishment is necessary and instrumental for achieving parental goals (Taylor, Hamvas, \& Paris, 2011).

\footnotetext{
${ }^{1}$ These countries are Albania, Andorra, Argentina, Austria, Benin, Bolivia, Brazil, Bulgaria, Cabo Verde, Congo, Costa Rica, Croatia, Cyprus, Denmark, Estonia, Finland, FYR Macedonia, Germany, Greece, Honduras, Hungary, Iceland, Ireland, Israel, Kenya, Latvia, Liechtenstein, Lithuania, Luxembourg, Malta, Mongolia, Montenegro, Netherlands, New Zealand, Nicaragua, Norway, Paraguay, Peru, Poland, Portugal, Republic of Moldova, Romania, San Marino, Slovenia, South Sudan, Spain, Sweden, Togo, Tunisia, Turkmenistan, Ukraine, Uruguay, Venezuela.
} 
International Journal of Child, Youth and Family Studies (2017) 8(3-4): 127-153

Approval also amplifies the impact of negative affect. For example, under conditions of frustration, approval of physical punishment fully mediates the relation between a history of physical punishment and the choice to use it (Russa, Rodriguez, \& Silvia, 2014). Similarly, the association between parenting stress and child abuse potential appears to be moderated by the strength of parents' beliefs in the value of physical punishment (Crouch \& Behl, 2001). Therefore, reducing approval of the practice is likely to be an effective prevention strategy.

In the case of use of physical punishment, early modeling almost certainly plays a role (Bandura, 1997). When a child is exposed to physical punishment, it enters the child's behavioral repertoire. The more frequent the exposure, the fewer opportunities the child has to learn alternative responses. Therefore, it is not surprising that frequency of exposure as a child predicts frequency of use as an adult (Bailey, Hill, Oesterle, \& Hawkins, 2009; Bower-Russa, Knutson \& Winebarger, 2001; Wang \& Xing, 2014; Woodward \& Fergusson, 2002).

What is more difficult to explain is the common finding that childhood experience of physical punishment predicts adult approval of it (Buntain-Ricklefs, Kemper, Bell, \& Babonis, 1994; Deater-Deckard, Lansford, Dodge, Pettit, \& Bates, 2003; Gagné, Tourigny, Joly, \& Pouliot-Lapointe, 2007; Lunkenheimer, Kittler, Olson, \& Kleinburg, 2006; Straus, 1994). It could be argued that this relationship defies logic. Classical learning theory would predict that the association between physical punishment and pain should condition an avoidance response to the very idea of physical punishment. The experience of being burned by a candle in childhood likely will be used in adulthood to protect one's child from the same pain; most parents would not draw on the experience of being burned to suggest that touching a candle is a good teaching tool. Yet many parents will view the pain of physical punishment as providing a valuable and effective lesson that should be repeated with their own children. At the same time, many individuals who were physically punished as children neither repeat the experience with their own children nor approve of it. A simple modeling process cannot explain this variation in the relationship between childhood experience and adult approval.

Perhaps it is the physical characteristics of the experience that influence later approval of it. For example, a higher frequency of childhood exposure to physical punishment reduces exposure to other means of resolving conflict, potentially resulting in a lower level of parenting knowledge and a stronger belief that physical punishment is normal and non-abusive. Indeed, the frequency of physical punishment experienced in childhood has been found to be related to adult approval of it (Gagné at al., 2007). It could also be hypothesized that the severity of the child's experience influences approval in adulthood. While the severity of reported physical punishment in childhood is related to approval ratings in young adulthood, this relationship appears to follow an inverted-U pattern; the weakest approval level has been found among those with either the least or the most severe childhood experiences (Ateah \& Parkin, 2002; Gagné et al., 2007; Kelder, McNamara, Carlson, \& Lynn, 1991; Murphy-Cowan \& Stringer, 1999). 
Yet a substantial proportion of individuals who experienced severe physical punishment do approve of it (Bower \& Knutson, 1996; Bower-Russa et al., 2001; Miller \& Knutson, 1997; Orhon, Ulukol, Bilonger, \& Gulnar, 2006; Rodriguez \& Sutherland, 1999). For example, in a 10year longitudinal study of more than 11,000 adults only $26 \%$ of those who experienced severe physical punishment (e.g., punching, kicking, choking) labeled themselves as maltreated (Knutson \& Selner, 1994). Therefore, it may not be the physical experience itself that shapes approval, but one's cognitive interpretation of that experience; that is, an appraisal of one's experiences as non-abusive may contribute to the intergenerational transmission of approval. Further, the more one's disciplinary experiences are perceived as deserved, the more likely one is to consider physical punishment to be appropriate and non-abusive (Kelder et al., 1991; Rausch \& Knutson, 1991). Therefore, a second relevant cognitive dimension may be a perception that one's childhood physical punishment was deserved.

The experience of physical punishment also has an affective dimension. While it usually elicits negative affect, primarily sadness and anger (Dobbs, Smith, \& Taylor, 2006; Saunders \& Godard, 2008), some children might experience positive affect. Indeed, approval levels are higher in cultures where physical punishment is defined as an act of love than where it is viewed as an act of violence (Durrant et al., 2003; Gopaul-McNichol, 1999; Payne, 1989; Statistics Sweden, 1996). Perhaps children who interpret physical punishment as an act of love are more likely to approve of it later in life than are children who experience it as rejection.

Physical punishment also has a contextual dimension. It might be accompanied by power assertion (e.g., additional punishment), emotional abuse (e.g., yelling), emotional support (e.g., apology), or induction (e.g., explanation). Perhaps physical punishment accompanied by induction suggests to the child that it is intended for his or her own good, which might contribute to later approval of it.

In the present study, we attempted to assess the relative contributions of young adults' perceptions of the physical, cognitive, affective, and contextual dimensions of their childhood experiences of physical punishment to their current approval of this practice in order to identify routes to its prevention. On the basis of findings demonstrating that adult approval is not consistently related to the severity of one's experiences (Knutson \& Selner, 1994), we hypothesized that adults' perceptions of the cognitive, affective, and contextual dimensions of their childhood experiences would be more powerful predictors of their current approval than their perceptions of the physical dimension of their experiences. If this is the case, reducing the severity of physical punishment will be less successful in reducing its approval than will shifting interpretations of the experience. 
International Journal of Child, Youth and Family Studies (2017) 8(3-4): 127-153

\section{Method}

\section{Participants}

A sample of 480 first-year university students was drawn from three Canadian provinces: Nova Scotia (Cape Breton University; 43.1\%), Manitoba (University of Manitoba; 30.3\%), and Saskatchewan (University of Saskatchewan and First Nations University of Canada; 35.6\%). Six participants' data were incomplete and omitted from the analyses. The sample was drawn from the first-year university population because these individuals are likely to be leaving adolescence and entering young adulthood. Therefore, they are chronologically close to both their childhood experiences and parenthood. The study sample of 474 students had a mean age of 21 years. Most were non-parents $(88.3 \%)$, female $(73.1 \%)$, single $(57.5 \%)$, and Caucasian (76.0\%). We acknowledge that this sample may not be representative of the population in terms of their characteristics, experiences, or attitudes. However, their accessibility made it possible to obtain a sample of considerable size across diverse regions of the country.

\section{Measures}

The Parenting and Punishment Questionnaire was developed for this study. ${ }^{2}$ The items were rationally derived to reflect constructs hypothesized or found to be relevant in the theoretical and empirical literature on physical punishment, as well as those often suggested to be important in the public media. The questionnaire measured participants' approval of physical punishment, as well as their experience of its four dimensions (physical, cognitive, affective, contextual). It was approved by an ethics review committee at each participating university. Each participant signed a consent form prior to completing the survey.

The questionnaire required some retrospective reporting of childhood physical punishment experiences. While retrospective measures have limitations (e.g., inaccurate recall), there is evidence to suggest that these measures can still yield valid findings; for example, data obtained through a prospective longitudinal study were consistent with those obtained through retrospective self-reports (Deater-Deckard et al., 2003). Retrospective reports of childhood experiences of parental aggression correspond with observers' assessments of those same parental behaviors 10 years earlier, as long as the retrospective measures are objective and specific (Prescott et al., 2000). Thus, in the present study, our variables were operationalized using the Parenting and Punishment Questionnaire.

Outcome variable: Approval of physical punishment. Respondents indicated their levels of agreement with each of 13 statements on a 5-point scale ranging from 1 (strongly disagree) to 5 (strongly agree). The statements reflected both positive (P) and negative (N) attitudes toward spanking (the $\mathrm{N}$ items were reverse scored): "Parents know best how to deal with their own children" (P); "Too much fuss is made about spanking, it's no big deal" (P); "Some children need to be spanked for their own good" $(\mathrm{P})$; "There is never a good reason to

${ }^{2}$ A copy of the complete questionnaire is available from the first author upon request. 
International Journal of Child, Youth and Family Studies (2017) 8(3-4): 127-153

spank a child" $(\mathrm{N})$; "Spanking is harmful" $(\mathrm{N})$; "There should be a law against spanking children" $(\mathrm{N})$; "I was spanked and I am fine" (P); "I will spank my children if they need it" (P); "It is okay to spank as long as you do not harm the child" (P); "Spanking teaches children right from wrong" (P); "All spanking is abusive" $(\mathrm{N})$; "Spanking is okay as long as it is done by the child's parent" (P); "Spanking does no good at all" $(\mathrm{N})$. These items had strong internal consistency (Cronbach's $\alpha=.94$ ). The mean of ratings on the 13 items constituted the approval score, with a possible range of 1 to 5 , with higher scores indicating higher levels of approval.

Predictor variables: Physical, cognitive, affective, and contextual dimensions of childhood physical punishment experience. The questionnaire provided the following standardized information to participants before they completed the items related to their physical punishment experiences: "We want to know about your experience of physical punishment as a child or teenager. Physical punishment includes spanking, slapping, shaking, hitting with a hand or object, kicking, punching, making you stand still or kneel for a long time, and similar acts." They were then asked to indicate whether they were physically punished at least once as a child or teenager by someone they lived with.

To control for diverse intraindividual experiences across caregivers, those who indicated that they had been physically punished then were asked to indicate, of the people they lived with, all those who physically punished them at some time. They were then asked to indicate which one of those people physically punished them the most. They were asked to respond to all subsequent questions with reference to the individual who physically punished them the most.

Physical dimension. To assess the frequency with which they experienced physical punishment, respondents were asked to rate, on a 5-point scale ranging from 0 (never) to 4 ( $a$ lot), how often they experienced each of 10 forms of physical punishment: mild spanking with a hand, hard spanking with a hand, hitting with a fist, punching or choking, pushing against a wall, ear- or hair-pulling, hitting with an object, being forced to stand still for a long time, being forced to kneel on hard objects, and any other form of physical punishment. The ratings had adequate internal consistency (Cronbach's $\alpha=.75$ ). The highest rating across the 10 items was used to define a frequency of physical punishment score, which could range from 0 to 4 , with zero indicating no physical punishment and higher scores indicating higher frequencies of physical punishment. For descriptive purposes, participants who indicated being hit with objects were asked to specify the object(s) used.

The assessment of physical punishment severity is challenging. A researcher's placement of acts into a severity hierarchy might not coincide with a child's subjective assessment of the same acts. Further, "severity" is multidimensional, including aspects such as degree of force, intensity of pain, degree of emotional distress, and the act's duration, as well as the verbal and nonverbal communications (e.g., facial expression) that accompany it. Therefore, placing physically punitive acts into a hierarchy of severity on the basis of the act itself is overly simplistic and of questionable validity. 
International Journal of Child, Youth and Family Studies (2017) 8(3-4): 127-153

Rather than imposing a severity hierarchy, we constructed a variable reflecting our research question: Will limiting the severity of physical punishment or delegitimizing "mild spanking" be the more effective route to prevention? The three categories were "no physical punishment", "mild spanking with the hand", and "other physical punishment" (hard spanking with a hand, hitting with a fist, punching or choking, pushing against a wall, ear- or hair-pulling, hitting with an object, being forced to stand still for a long time, being forced to kneel on hard objects). "No physical punishment" received a severity score of 0 and "mild spanking with the hand" received a severity score of 1 . Those who reported experiencing "other physical punishment" received a score of 1 for each type they experienced at least rarely. Therefore, the severity score could range from 0 to 10 , with higher scores reflecting a greater number of "more severe" acts.

Three items measuring physical harm supplemented this measure of severity:

- whether injury was ever sustained as a result of punishment (no $=0$, yes $=1)$;

- whether medical treatment was ever required as a result of punishment and, if so, how often (no $=0$, once $=1$, twice $=2,3$ or more times $=3$ ); and

- whether hospitalization was ever required as a result of punishment and, if so, how often (no $=0$, once $=1$, twice $=2,3$ or more times $=3$ ).

These three scores were summarized into a total physical harm score, which could range from 0 to 7. Participants who did not experience physical punishment or who were not injured as a result of punishment received a physical harm score of 0 . Those who were injured but not medically treated or hospitalized received a physical harm score of 1. Participants received an additional score of 1 for each medical treatment or hospitalization they reported.

Cognitive dimension. Perceived abusiveness refers to participants' beliefs regarding whether the physical punishment they experienced was within the normal range or was excessive. This construct was assessed with two items: "Do you think that the punishment you received was too harsh?" (no $=0$, yes $=1$ ); and "Do you think that you were physically abused?" (no $=0$, yes $=1$ ). The items had adequate internal consistency (Cronbach's $\alpha=.69$ ). The mean score on the two items was used to construct a perceived abusiveness score that could range from 0 to 2 , with higher scores indicating a stronger belief that the punishment was abusive.

Perceived deservedness was assessed on a five-point scale ranging from 1 (strongly disagree) to 5 (strongly agree) indicating agreement with the following statements: "I was only physically punished when I deserved it"; "The physical punishment I received was unfair". The second item was reverse scored. The items had good internal consistency (Cronbach's $\alpha=.80$ ). The mean score on the two items was used to define a perceived deservedness score (possible range: 1-5; higher scores indicate stronger belief that the punishment was deserved). 
International Journal of Child, Youth and Family Studies (2017) 8(3-4): 127-153

Affective dimension. Short-term affective impact of physical punishment was assessed on a five-point scale ranging from 0 (never) to 4 (always) indicating the frequency with which participants felt each of a list of positive (relieved, okay, loved) and negative (sad, lonely, confused, scared, humiliated, angry, guilty) emotions immediately after the experience. The three positive emotion scores (Cronbach's $\alpha=.57$ ) were averaged to create a positive short-term affective appraisal score (possible range: 0-4; higher scores indicate more positive short-term affective impact). The seven negative emotion scores (Cronbach's $\alpha=.80$ ) were averaged to create a negative short-term affective appraisal score (possible range: $0-4$; higher scores indicate more negative short-term affective impact).

Long-term affective impact of physical punishment was assessed on a five-point scale ranging from 1 (strongly disagree) to 5 (strongly agree) indicating agreement with the following three statements: "Physical punishment showed me I was cared for"; "Being physically punished improved my relationship with the person who punished me"; "Being physically punished harmed my relationship with the person who punished me." The third item was reverse scored. The ratings on the three items had adequate internal consistency (Cronbach's $\alpha=.75$ ). Participants' scores were averaged to create a long-term affective appraisal score (possible range: 1-5; higher scores indicate more positive long-term affective impact).

Contextual dimension. Respondents rated the frequency with which physical punishment was accompanied by nine other parental acts on a five-point scale ranging from 0 (never) to 4 ( $a$ lot). The acts represented induction (explaining why the child was being punished), power assertion (removing privileges, grounding, time out), emotional abuse (humiliating, yelling, threatening), or emotional support (expressing love, apologizing). Scores were averaged within each category to yield inductive (possible range: 0-4), power assertive (possible range: 0-4, Cronbach's $\alpha=.64$ ), emotionally abusive (possible range: $0-4$, Cronbach's $\alpha=.81$ ), and emotionally supportive (possible range: $0-4$, Cronbach's $\alpha=.73$ ) scores. Higher scores indicate higher frequencies. 
International Journal of Child, Youth and Family Studies (2017) 8(3-4): 127-153

\begin{abstract}
Analysis
The analysis was conducted in three stages. First, we generated descriptive statistics on the sample's demographic characteristics, approval of physical punishment, and prevalence and types of childhood physical punishment experienced and who administered it, as well as each of the predictor variables. Second, we examined the impact of experiencing childhood physical punishment on adult approval scores before and after accounting for participants' demographic characteristics. Third, focusing on the subsample who reported experiencing childhood physical punishment, we conducted multiple regression analyses to assess the relative contributions of the physical, cognitive, affective, and contextual dimensions of childhood physical punishment to adult approval.
\end{abstract}

\title{
Results
}

\section{Descriptive Statistics}

Demographic variables. The three subsamples from Manitoba, Nova Scotia, and Saskatchewan differed demographically. Gender differed significantly by site $\left(\chi^{2}=23.18, d f=2\right.$, $p<.001$ ), with a smaller proportion of males in Manitoba than in Nova Scotia and Saskatchewan. Differences in marital status $\left(\chi^{2}=6.06, d f=2, p=.049\right)$ and parenthood status $\left(\chi^{2}=31.62, d f=2, p<.001\right)$ indicated that the smallest proportion of singles and the largest proportion of parents lived in Saskatchewan, followed by Manitoba and Nova Scotia. The Nova Scotia subsample had a higher proportion of Caucasian participants than the other two sites $\left(\chi^{2}=\right.$ 29.25, $d f=2, p<.001)$.

Approval of physical punishment. Table 1 presents the proportions of respondents who strongly disagreed/disagreed, sort of agreed, and strongly agreed/agreed with each item on the approval of physical punishment scale. Only one quarter $(25.9 \%)$ agreed or strongly agreed that they will spank their children, but approximately $40 \%$ agreed or strongly agreed that spanking is acceptable as long as the child is not harmed. Almost two thirds (63\%) agreed or strongly agreed with the statement, "I was spanked and I am fine." However, approximately half (48.9\%) of respondents agreed or strongly agreed that all spanking is abusive, and $60.5 \%$ agreed or strongly agreed that there should be a law against spanking children.

For each participant, an approval of physical punishment score was calculated using the average rating across the 13 items, with higher scores indicating higher levels of approval. The mean physical punishment approval score was 3.1 (possible range: 1-5; actual range: 1-5; $S D=0.9)$. 
Table 1 Approval of Physical Punishment $(N=474)$

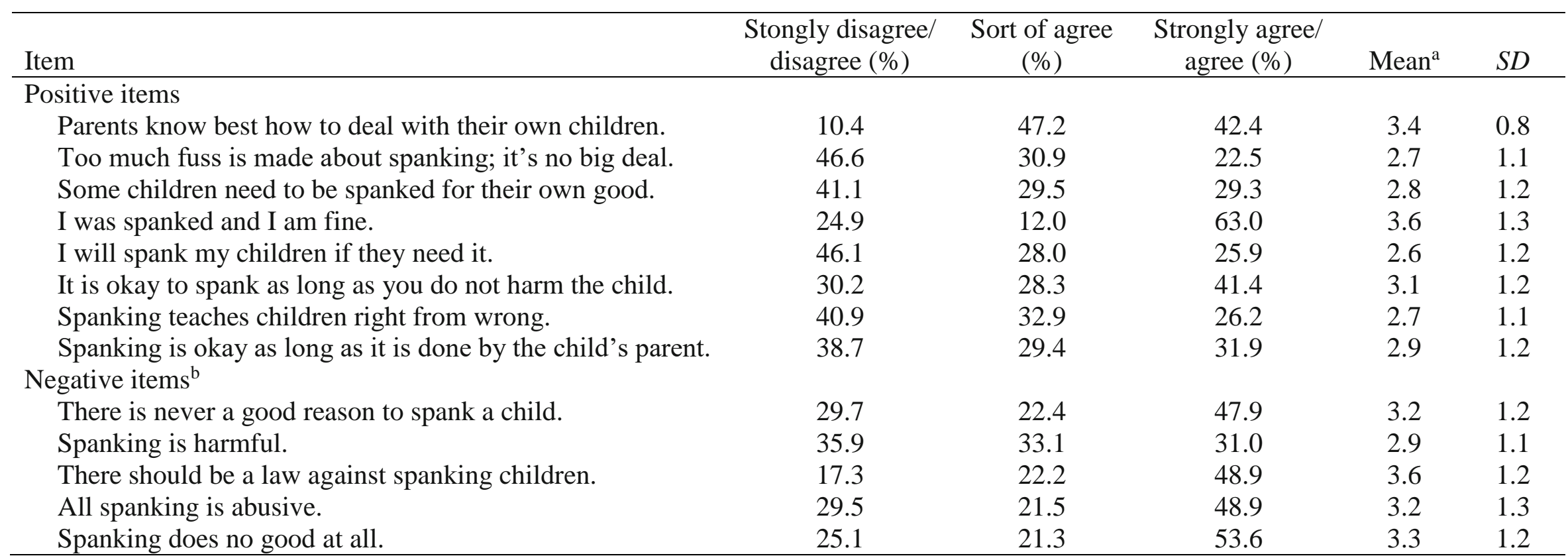

${ }^{a}$ Mean agreement rating on a scale of 1 (strongly disagree) to 5 (strongly agree).

${ }^{\mathrm{b}}$ Items are reverse scored. 
International Journal of Child, Youth and Family Studies (2017) 8(3-4): 127-153

Frequency of physical punishment. Most (73.4\%) respondents reported that they had experienced physical punishment at least rarely (77.0\% of males, $72.0 \%$ of females). Among the subsample of 348 subjects who reported experiencing physical punishment, the most prevalent types were mild spanking with the hand (87.8\%) and hard spanking with the hand $(62.3 \%)$. Approximately one fourth of the sample had had their ears or hair pulled (25.7\%), been made to stand still for a long time $(23.1 \%)$, or been pushed against a wall $(22.5 \%)$. Smaller minorities had been hit with a fist (12.5\%), punched or choked (9.9\%), or made to kneel on hard objects (4.8\%). "Other" forms of physical punishment (15.1\%) were specified as slapping on the face $(30 \%$ of "other" responses), grabbing (30\%), kicking (20\%), throwing the child outside (10\%), and throwing cold water on the child (10\%).

One third of those who were physically punished had been hit with objects: belts (19\% of objects specified), wooden spoons (17.7\%), shoes (11.4\%), branches (10.1\%), and brooms $(8.9 \%)$. Also reported were switches, paddles, phones, newspapers, hairbrushes, remote controls, spatulas, TV cords, extension cords, metal bars, butter knives, drinking glasses, baby bottles, forks, pieces of plastic, pieces of conveyor belt, chairs, books, rulers, plates, canes, batteries, and "any object they could grab at the time" (each constituted $1.3 \%$ to $3.8 \%$ of objects specified).

People who administered physical punishment. When asked to identify all those who had physically punished them, respondents identified their mothers (81.3\%), fathers (73.6\%), siblings $(19.8 \%)$, grandmothers $(6.0 \%)$, grandfathers $(3.4 \%)$, aunts $(4.0 \%)$, uncles $(2.9 \%)$, stepmothers $(1.7 \%)$, stepfathers $(4.3 \%)$, foster mothers $(1.7 \%)$, foster fathers $(1.7 \%)$, and other (a boarder, people at institutions; 2.3\%). When asked which person had physically punished them the most, respondents indicated that this person was the father in $46.3 \%$ of cases, the mother in $44.8 \%$, and siblings in $4.4 \%$.

Physical dimension of physical punishment. Each of the 10 types of physical punishment was rarely or never experienced by a majority of participants, with the exception of mild spanking with the hand, which was experienced by $63.5 \%$ at least rarely (Table 2). The frequency score across all 10 types of physical punishment was 0 for $26.6 \%, 1$ for $23.4 \%, 2$ for $34.2 \%, 3$ for $10.8 \%$, and 4 for $5.1 \%$ of the participants. The mean frequency score was $1.4(S D=$ $1.1)$.

Among the 348 participants who experienced physical punishment, $22.1 \%$ experienced only mild spanking with the hand; $32.5 \%$ experienced one or more other types of physical punishment; $17.0 \%$ experienced two; $13.2 \%$ experienced three; and $15.2 \%$ experienced four. The participants who did not experience any physical punishment received a severity score of zero. The mean severity score was 2.1 (possible range: $0-10, S D=1.9$ ).

The majority of participants had not sustained injury (90.5\%) and very few required medical treatment $(2.1 \%)$ or hospitalization $(0.8 \%)$ as a result of punishment (Table 3 ). 
International Journal of Child, Youth and Family Studies (2017) 8(3-4): 127-153

Table 2 Frequency of Physical Punishment $(N=474)$

\begin{tabular}{lcccccc}
\hline $\begin{array}{l}\text { Type of physical punishment } \\
\text { experienced }\end{array}$ & $\begin{array}{c}\text { Never } \\
(\%)\end{array}$ & $\begin{array}{c}\text { Rarely } \\
(\%)\end{array}$ & $\begin{array}{c}\text { Sometimes } \\
(\%)\end{array}$ & $\begin{array}{c}\text { Quite often/ } \\
\text { a lot }(\%)\end{array}$ & Mean $^{\text {a }}$ & $S D$ \\
\hline $\begin{array}{l}\text { Mild spanking with hand only } \\
\text { Other physical punishment }\end{array}$ & 36.5 & 26.2 & 31.2 & 6.1 & 1.1 & 1.0 \\
$\quad$ Hard spanking with hand & 56.1 & 24.9 & 14.3 & 4.6 & 0.7 & 0.9 \\
$\quad$ Ear or hair pulled & 81.6 & 9.1 & 7.4 & 1.9 & 0.3 & 0.7 \\
Made to stand still & 83.8 & 8.6 & 4.0 & 3.6 & 0.3 & 0.8 \\
Pushed against wall & 84.2 & 7.8 & 6.8 & 1.3 & 0.3 & 0.7 \\
Hit with fist & 91.1 & 4.2 & 3.2 & 1.5 & 0.2 & 0.5 \\
Hit with an object & 75.3 & 11.6 & 9.3 & 3.8 & 0.4 & 0.9 \\
Punched or choked & 93.0 & 3.2 & 2.7 & 1.1 & 0.1 & 0.5 \\
Made to kneel on hard objects & 96.6 & 1.5 & 0.6 & 1.3 & 0.1 & 0.4 \\
Any other form & 94.5 & 2.1 & 1.5 & 1.9 & 0.1 & 0.5 \\
\hline
\end{tabular}

${ }^{\mathrm{a}}$ Mean frequency rating on a scale of 0 (never) to 4 (a lot).

Table 3 Injury, Medical Treatment, and Hospitalization After Physical Punishment $(N=474)$

\begin{tabular}{lc}
\hline Score & \% of sample $(n)$ \\
\hline Injury & \\
No & $90.5(429)$ \\
Yes & $9.5(45)$ \\
Medical treatment & \\
Never & $97.9(464)$ \\
Once & $1.7(8)$ \\
Twice & $0.2(1)$ \\
Three or more times & $0.2(1)$ \\
Hospitalization & \\
Never & $99.2(470)$ \\
Once & $0.6(3)$ \\
Twice & $0.2(1)$ \\
Three or more times & $0.0(0)$ \\
Total physical harm score & \\
0 & $90.5(429)$ \\
1 & $7.4(35)$ \\
2 & $1.1(5)$ \\
3 & $0.6(3)$ \\
4 & $0.2(1)$ \\
5 & $0.2(1)$ \\
6 & $0.0(0)$ \\
7 & $0.0(0)$ \\
\hline
\end{tabular}

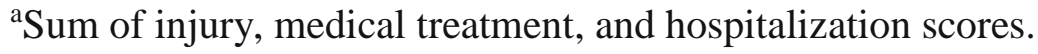


Cognitive dimension of physical punishment. Among those who reported childhood physical punishment, the mean perceived abusiveness score was $0.2(S D=0.3$; possible range: $0-1) ; 22.7 \%$ believed that their punishment was too harsh and $11.5 \%$ believed they were physically abused. The mean perceived deservedness score was 3.7 (possible range: 1-5; $S D=1.1$ ). The mean score on the item "I was only physically punished when I deserved it" was $3.6(S D=1.3$; possible range: $1-5)$. The mean score on the item "The physical punishment I received was unfair" was $2.3(S D=1.2$; possible range: $1-5)$. The latter item was reverse scored such that a higher score indicates a stronger belief that the punishment was fair.

Affective dimension of childhood physical punishment. Participants' affective impact appraisals were more negative than positive (Table 4). Among the short-term positive affective impact items "okay" had the highest mean score. The short-term negative impact items with the highest means were "sad" and "angry". The long-term affective impact item with the largest contribution was "Being physically punished harmed my relationship with the person who punished me.", with which one-quarter of participants indicated some level of agreement. When this item was reverse scored its mean became the highest $(6-2=4)$ among the three long-term affective impact items. 
International Journal of Child, Youth and Family Studies (2017) 8(3-4): 127-153

Table 4 Short- and Long-Term Affective Impact of Physical Punishment ( $n=348)$

\begin{tabular}{|c|c|c|c|c|c|}
\hline Measure & $\begin{array}{c}\text { Never/ } \\
\text { Rarely }(\%)\end{array}$ & $\begin{array}{l}\text { Sometimes } \\
(\%)\end{array}$ & $\begin{array}{l}\text { Usually/ } \\
\text { Always (\%) }\end{array}$ & Mean & $S D$ \\
\hline \multicolumn{6}{|l|}{ Short-term affective impact: Positive items } \\
\hline Relieved & 81.9 & 12.0 & 6.1 & 0.6 & 1.0 \\
\hline Okay & 45.2 & 29.7 & 25.1 & 1.6 & 1.2 \\
\hline Loved & 56.7 & 21.3 & 21.9 & 1.4 & 1.3 \\
\hline Total positive short-term impact score & & & & 1.2 & 0.9 \\
\hline \multicolumn{6}{|l|}{ Short-term affective impact: Negative items } \\
\hline Sad & 25.5 & 28.7 & 45.8 & 2.2 & 1.2 \\
\hline Lonely & 64.9 & 20.0 & 15.1 & 1.1 & 1.3 \\
\hline Confused & 66.8 & 20.4 & 12.8 & 1.1 & 1.2 \\
\hline Scared & 59.5 & 19.8 & 20.7 & 1.3 & 1.3 \\
\hline Humiliated & 69.1 & 13.7 & 17.2 & 1.1 & 1.3 \\
\hline Angry & 22.7 & 24.1 & 53.2 & 2.4 & 1.3 \\
\hline Guilty & 44.6 & 29.4 & 25.9 & 1.7 & 1.3 \\
\hline \multirow[t]{2}{*}{ Total negative short-term impact score } & & & & 1.6 & 0.9 \\
\hline & $\begin{array}{c}\text { Strongly disagree/ } \\
\text { Disagree }(\%)\end{array}$ & $\begin{array}{c}\text { Sort of } \\
\text { agree }(\%)\end{array}$ & $\begin{array}{c}\text { Strongly agree/ } \\
\text { Agree }(\%)\end{array}$ & & \\
\hline \multicolumn{6}{|l|}{ Long-term affective impact items } \\
\hline $\begin{array}{l}\text { Physical punishment showed me I was cared for. } \\
\text { Being physically punished improved my relationship }\end{array}$ & 45.8 & 32.9 & 21.3 & 2.6 & 1.1 \\
\hline with the person who punished me. & 58.0 & 26.7 & 15.4 & 2.4 & 1.1 \\
\hline $\begin{array}{l}\text { Being physically punished harmed my relationship } \\
\text { with the person who punished me. }\end{array}$ & 74.6 & 10.2 & 15.2 & 2.0 & 1.3 \\
\hline Total long-term affective impact score & & & & 3.0 & 1.3 \\
\hline
\end{tabular}


International Journal of Child, Youth and Family Studies (2017) 8(3-4): 127-153

Contextual dimension of childhood physical punishment. Induction was the most common context to accompany physical punishment at least rarely (88.4\% of cases; $M=2.53)$. It was followed by emotional support $(M=1.58)$, power assertion $(M=1.53)$, and emotional abuse $(M=1.49)$. The acts most likely to accompany physical punishment at least rarely were yelling (93.1\%), explaining (88.6\%), and removing privileges (87.8\%). See Table 5.

Table 5 Disciplinary Contexts Accompanying Physical Punishment (n=348)

\begin{tabular}{lcccccc}
\hline Context & $\begin{array}{c}\text { Never } \\
(\%)\end{array}$ & $\begin{array}{c}\text { Rarely } \\
(\%)\end{array}$ & $\begin{array}{c}\text { Sometimes } \\
(\%)\end{array}$ & $\begin{array}{c}\text { Quite often/ } \\
\text { A lot }(\%)\end{array}$ & Mean $^{\mathrm{a}}$ & $S D$ \\
\hline $\begin{array}{l}\text { Induction } \\
\quad \text { Explaining }\end{array}$ & 11.6 & 9.9 & 20.9 & 57.6 & 2.5 & 1.3 \\
$\quad \begin{array}{l}\text { Power assertion } \\
\quad \text { Removing privileges }\end{array}$ & 12.2 & 19.2 & 38.3 & 30.3 & 2.0 & 1.1 \\
$\quad$ Grounding & 29.6 & 14.5 & 22.6 & 33.2 & 1.7 & 1.4 \\
$\quad$ Time out & 56.5 & 15.3 & 16.5 & 11.8 & 0.9 & 1.2 \\
Emotional abuse & & & & & & \\
$\quad$ Humiliating & 61.4 & 14.9 & 14.9 & 8.8 & 0.7 & 1.1 \\
$\quad$ Yelling & 6.9 & 14.4 & 32.0 & 46.7 & 2.4 & 1.2 \\
$\quad$ Threatening & 40.1 & 18.6 & 20.1 & 21.2 & 1.3 & 1.3 \\
Emotional support & & & & & & \\
$\quad$ Expressing love & 30.2 & 19.2 & 16.9 & 33.7 & 1.7 & 1.5 \\
$\quad$ Apologizing & 33.9 & 18.4 & 23.7 & 24.0 & 1.5 & 1.3 \\
\hline
\end{tabular}

${ }^{\mathrm{a}}$ Mean frequency rating on a scale from 0 (never) to 4 (a lot).

\section{Regression Analysis - Full Sample}

The mean physical punishment approval score was significantly higher among participants who reported being physically punished than among those who did not ( $M$ difference $=0.770, p<.001)$. Approval scores did not differ based on site, age, parental status, marital status, or ethnic identity. This was at least partially due to the fact that some demographic characteristics were not adequately represented in the study sample. The only demographic variable to yield a significant difference was gender. Males obtained a higher mean approval score than females (mean difference $=0.288, p=.0019$ ). The regression model including gender and childhood physical punishment experience explained $16 \%$ of the variation in approval scores.

Among the predictor variables, only the physical dimension of physical punishment could be quantified for participants who did not experience any physical punishment. Therefore, we examined frequency, severity, and harm scores as measures of physical punishment experience. The relationship between frequency and adult approval was quadratic (concave), with higher approval scores among participants who experienced moderate frequency levels than among those who experienced low or high frequencies. The regression model that included gender 
International Journal of Child, Youth and Family Studies (2017) 8(3-4): 127-153

$(p=.001)$ and frequency $(p<.0001)$ with a quadratic term $(p<.0001)$ explained $18.5 \%$ of the variation in approval of physical punishment. The harm score was more informative than the severity score in explaining the variation in approval. Adding severity increased the adjusted $R^{2}$ to $19.5 \%$, while adding harm increased it to $21.6 \%(p<.0001)$. Therefore, the best model included gender, frequency, and harm (Table 6).

Table 6 Results of the Multiple Regression Analyses for the Full Sample $(N=474)$

\begin{tabular}{lcccc}
\hline Variable & $B$ & $S E B$ & $\beta$ & $p$ \\
\hline (Intercept) & 2.69 & 0.09 & 0.22 & $<0.0001$ \\
Gender: Female $_{\text {Frequency }}$ & -0.27 & 0.08 & -0.30 & 0.0012 \\
Frequency $^{2}$ & 0.76 & 0.09 & 0.97 & $<0.0001$ \\
Harm & -0.14 & 0.03 & -0.64 & $<0.0001$ \\
\hline
\end{tabular}

Note: Adjusted $R^{2}=0.216$.

\section{Regression Analysis — Physically Punished Subsample}

The impacts of the physical, cognitive, affective, and contextual dimensions of childhood physical punishment on the approval scores of physically punished participants were investigated using multiple regression. We included gender as a significant demographic variable. The fitted regression model (Table 7) explained $34 \%$ of the variation in approval. As in the full sample, males obtained a higher mean approval score than females. Frequency had a linear effect on the approval scores in the physically punished subsample, and it was the most significant physical dimension predictor $(p=.052)$. Of the cognitive dimension predictors, perceived deservedness of physical punishment was highly significant $(p<.0001)$. The only significant affective dimension predictor was long-term affective impact appraisal $(p<.0001)$. None of the cognitive dimension variables contributed anything further to the model.

It is important to note that the predictor variables showed some dependencies within and across dimensions (Table 8). The correlations confirmed that long-term affective impact appraisal and perceived deservedness were the most significant predictors of approval. The correlations among most predictors were weak to moderate. However, long-term affective impact appraisal, perceived deservedness, perceived abusiveness, and emotional abuse showed stronger correlations among themselves and with other variables. Nevertheless, our checks of the model in Table 7 did not indicate any multicollinearity issues (the highest variance inflation factor was 3.2). Thus, the best regression model included gender, frequency, deservedness, and long-term affective impact appraisal. 
International Journal of Child, Youth and Family Studies (2017) 8(3-4): 127-153

Table 7 Results of Multiple Regression Analyses for Physically Punished Subsample $(n=348)$

\begin{tabular}{lcccc}
\hline Variable & $B$ & $S E B$ & $\beta$ & $p$ \\
\hline Intercept) & 1.43 & 0.26 & 0.22 & $<0.0001$ \\
Gender: Female & -0.25 & 0.08 & -0.31 & 0.0036 \\
Physical dimension & & & & \\
$\quad$ Frequency & 0.11 & 0.05 & 0.11 & 0.0518 \\
$\quad$ Severity & 0.04 & 0.03 & 0.08 & 0.2170 \\
$\quad$ Harm & -0.10 & 0.08 & -0.07 & 0.2211 \\
Cognitive dimension & & & & \\
$\quad$ Abusiveness & -0.13 & 0.19 & -0.05 & 0.4972 \\
$\quad$ Deservedness & 0.29 & 0.06 & 0.40 & $<0.0001$ \\
Affective dimension & & & & \\
$\quad$ Short-term negative impact appraisal & 0.06 & 0.06 & 0.07 & 0.3041 \\
$\quad$ Short-term positive impact appraisal & -0.08 & 0.05 & -0.09 & 0.0983 \\
$\quad$ Long-term impact appraisal & 0.25 & 0.06 & 0.29 & $<0.0001$ \\
Contextual dimension & & & & \\
$\quad$ Induction & 0.02 & 0.03 & 0.04 & 0.5014 \\
$\quad$ Power assertion & -0.07 & 0.04 & -0.08 & 0.1122 \\
$\quad$ Emotional abuse & 0.05 & 0.05 & 0.07 & 0.3030 \\
$\quad$ Emotional support & -0.06 & 0.03 & -0.09 & 0.0861 \\
\hline
\end{tabular}

Note. Adjusted $R^{2}=0.340$. 
International Journal of Child, Youth and Family Studies (2017) 8(3-4): 127-153

Table 8 Correlations among Predictor and Outcome Variables in the Physically Punished Subsample $(n=348)$

\begin{tabular}{|c|c|c|c|c|c|c|c|c|c|c|c|c|c|}
\hline & 1 & 2 & 3 & 4 & 5 & 6 & 7 & 8 & 9 & 10 & 11 & 12 & 13 \\
\hline & Approval & Frequency & Severity & Harm & Abusive & Deserved & $\begin{array}{c}\text { Short-term } \\
\text { negative }\end{array}$ & $\begin{array}{c}\text { Short-term } \\
\text { positive }\end{array}$ & $\begin{array}{l}\text { Long-term } \\
\text { affective }\end{array}$ & Induction & $\begin{array}{c}\text { Power } \\
\text { Assertion } \\
\end{array}$ & $\begin{array}{c}\text { Emotional } \\
\text { abuse }\end{array}$ & $\begin{array}{c}\text { Emotional } \\
\text { support }\end{array}$ \\
\hline 1 & 1.00 & 0.01 & -0.09 & -0.23 & -0.38 & 0.52 & -0.24 & 0.13 & 0.49 & 0.24 & 0.01 & -0.21 & 0.03 \\
\hline 2 & 0.01 & 1.00 & 0.56 & 0.36 & 0.38 & -0.26 & 0.36 & -0.09 & -0.16 & -0.09 & 0.29 & 0.45 & -0.02 \\
\hline 3 & -0.09 & 0.56 & 1.00 & 0.46 & 0.45 & -0.43 & 0.43 & -0.02 & -0.29 & -0.22 & 0.19 & 0.52 & -0.16 \\
\hline 4 & -0.23 & 0.36 & 0.46 & 1.00 & 0.57 & -0.45 & 0.31 & -0.17 & -0.33 & -0.24 & 0.03 & 0.35 & -0.13 \\
\hline 5 & -0.38 & 0.38 & 0.45 & 0.57 & 1.00 & -0.72 & 0.58 & -0.26 & -0.62 & -0.35 & 0.02 & 0.52 & -0.18 \\
\hline 6 & 0.52 & -0.26 & -0.43 & -0.45 & -0.72 & 1.00 & -0.52 & 0.31 & 0.73 & 0.47 & 0.04 & -0.54 & 0.24 \\
\hline 7 & -0.24 & 0.36 & 0.43 & 0.31 & 0.58 & -0.52 & 1.00 & -0.18 & -0.47 & -0.24 & 0.22 & 0.62 & -0.03 \\
\hline 8 & 0.13 & -0.09 & -0.02 & -0.17 & -0.26 & 0.31 & -0.18 & 1.00 & 0.39 & 0.31 & 0.06 & -0.24 & 0.39 \\
\hline 9 & 0.49 & -0.16 & -0.29 & -0.33 & -0.62 & 0.73 & -0.47 & 0.39 & 1.00 & 0.48 & 0.04 & -0.52 & 0.28 \\
\hline 10 & 0.24 & -0.09 & -0.22 & -0.24 & -0.35 & 0.47 & -0.24 & 0.31 & 0.48 & 1.00 & 0.22 & -0.33 & 0.43 \\
\hline 11 & 0.01 & 0.29 & 0.19 & 0.03 & 0.02 & 0.04 & 0.22 & 0.06 & 0.04 & 0.22 & 1.00 & 0.19 & 0.18 \\
\hline 12 & -0.21 & 0.45 & 0.52 & 0.35 & 0.52 & -0.54 & 0.62 & -0.24 & -0.52 & -0.33 & 0.19 & 1.00 & -0.16 \\
\hline 13 & 0.03 & -0.02 & -0.16 & -0.13 & -0.18 & 0.24 & -0.03 & 0.39 & 0.28 & 0.43 & 0.18 & -0.16 & 1.00 \\
\hline
\end{tabular}

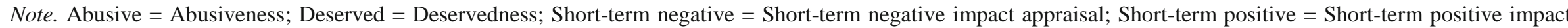
appraisal; Long-term affective = Long-term affective impact appraisal. 
International Journal of Child, Youth and Family Studies (2017) 8(3-4): 127-153

\section{Discussion}

The purpose of this study was to explore the theoretical question of whether the approval of physical punishment would be most effectively addressed through strategies focused on reducing the severity of physical punishment or strategies focused on transforming the legitimacy of physical punishment per se. Our findings demonstrated that the severity of childhood physical punishment was not strongly related to its approval in adulthood. The best predictor of approval was the degree to which childhood physical punishment experiences were perceived as deserved, followed by their long-term emotional impact. Interestingly, the context of childhood physical punishment experiences did not predict approval, suggesting that parental actions accompanying physical punishment are less important than children's cognitive and affective appraisals of their experiences.

The belief that physical punishment is deserved appears to be an important factor in approval of physical punishment. If defining physical punishment as deserved strengthens approval, and approval strengthens the likelihood of physical punishment use (Holden et al., 1995), redefining physical punishment from an act deserved by the child to an act that is the responsibility of the aggressor will be an important component of prevention strategies. While considerable progress has been made in establishing that other forms of physical aggression (i.e., peer-to-peer aggression, adult-to-adult aggression, stranger-to-child aggression) are never deserved, many victims of parent-to-child aggression believe that they deserved it - even among a university sample. Therefore, a key element of prevention will be to shift this perception. It is interesting that the only form of interpersonal aggression that is called "punishment" is that directed by adults towards children. The implicit assumption underlying this label is that the child did something that merited the adult's aggression. When a child hits another child, this is called "aggression" or "bullying", which places the responsibility for the action on the aggressor, not on the victim. The same can be said of "partner violence" and "dating violence". It is only in the case of adult-to-child aggression that we use language implying that the act was deserved.

A study carried out in nine countries revealed that parents' perceptions of physical punishment were key predictors of their use of it (Lansford et al., 2015). Its authors concluded that policies aimed at altering parents' perceptions of physical punishment as normative and needed have the potential to change behavior at the cultural level. Laws like those in Canada, the United States, and the United Kingdom that merely attempt to limit the severity of physical punishment are counter-productive to this process. Rather than redefining physical punishment as an illegitimate act of aggression, such laws target only its severity which, as the present findings suggest, is unlikely to contribute to attitude shifts. In fact, Canada's law explicitly affirms that mild corporal punishment is "justified"; that is, deserved by the child. An analysis of public responses to the 2004 decision of the Supreme Court of Canada, which did not alter the 
International Journal of Child, Youth and Family Studies (2017) 8(3-4): 127-153

wording of Section 43, found that it was interpreted by many as confirmation that physical punishment is a justifiable act (Durrant et al., 2008).

In contrast, a growing number of countries are redefining all physical punishment as violence. The present findings indicate that this approach to legal reform is likely to be more effective in transforming social norms. In Germany, for example, where physical punishment was prohibited in 2000, parents have become more likely to define slaps and smacks as "violent" and "mild" physical punishment has declined (Federal Ministry for Family Affairs, Senior Citizens, Women and Youth, \& Federal Ministry of Justice, 2003). In Sweden, where physical punishment was prohibited in 1979 , only $11 \%$ of Swedes were "positively inclined toward even the mildest forms of physical punishment" by 1996 and the practice had become extremely rare (Durrant \& Janson, 2005; Statistics Sweden, 1996). By 2011, 92\% of Swedish parents believed that it is wrong to slap a child even if the parent is very angry, and only $3 \%$ reported hitting their child in the previous year (Janson, Jernbro, \& Långberg, 2011). In a comparative study of five European nations, parents' knowledge of physical punishment's legality had a direct effect on their definitions of violence and approval of physical punishment, as well as on the frequency of their use of severe physical punishment (Bussman, Erthal, \& Schroth, 2011).

The present study has several limitations. First, although participants came from several regions of the country, the sample was not randomly drawn so the findings cannot be reliably generalized to the Canadian population. Second, $73 \%$ of the participants were female and $76 \%$ were Caucasian, so there may be gender and cultural biases in participants` responses. Third, few participants experienced physical injury or needed medical treatment as a result of physical punishment so the range of scores on the physical harm scale was severely restricted. Fourth, even the best regression model accounted for less than $35 \%$ of the variance in approval scores, indicating that additional aspects of childhood physical punishment and its approval merit investigation.

Nonetheless, the present findings do strongly suggest that perception of child physical punishment as deserved is a more powerful factor in its approval than the severity of the punishment experienced. Therefore, attitude change should be a key element of prevention strategies. Laws that attempt to draw lines between "reasonable" and "unreasonable" physical punishment will be counterproductive; laws that prohibit all physical punishment have strong potential to shift attitudes by redefining physical punishment as violence in the public mind.

\section{Acknowledgement}

We are grateful for Katharine Covell's substantial contributions to this study. 
International Journal of Child, Youth and Family Studies (2017) 8(3-4): 127-153

\section{References}

Ateah, C., \& Durrant, J. E. (2005). Maternal use of physical punishment in response to child misbehavior: Implications for child abuse prevention. Child Abuse and Neglect, 29, 177193. doi:10.1016/j.chiabu.2004.10.010

Ateah, C. A., \& Parkin, M. (2002). Childhood experiences with, and current attitudes toward, corporal punishment. Canadian Journal of Community Mental Health, 21, 35-45. doi:10.7870/cjcmh-2002-0004

Bailey, J. A., Hill, K. G., Oesterle, S., \& Hawkins, J. D. (2009). Parenting practices and problem behavior across three generations: Monitoring, harsh discipline, and drug use in the intergenerational transmission of externalizing behavior. Developmental Psychology, 45, 1214-1226. doi:10.1037/a0016129

Bandura, A. (1997). Social learning theory. Englewood Cliffs, NJ: Prentice-Hall.

Belsky, J. (1980). Child maltreatment: An ecological integration. American Psychologist, 35, 320-335. doi:10.1037/0003-066X.35.4.320

Bower, M. E., \& Knutson, J. F. (1996). Attitudes toward physical discipline as a function of discipline history and self-labeling as physically abused. Child Abuse \& Neglect, 20, 689699. doi:10.1016/0145-2134(96)00057-9

Bower-Russa, M. E., Knutson, J. F., \& Winebarger, A. (2001). Disciplinary history, adult disciplinary attitudes, and risk for abusive parenting. Journal of Community Psychology, 29, 219-240. doi:10.1002/jcop.1015

Buntain-Ricklefs, J. J., Kemper, K. J., Bell, M., \& Babonis, T. (1994). Punishments: What predicts adult approval. Child Abuse \& Neglect, 18, 945-955. doi:10.1016/S0145$\underline{2134(05) 80005-5}$

Bussman, K.-D., Erthal, C., \& Schroth, A. (2011). Effects of banning corporal punishment in Europe: A five-nation comparison. In J. E. Durrant and A. B. Smith (Eds.), Global pathways to abolishing physical punishment: Realizing children's rights (pp.299-322). New York, NY: Routledge.

Clément, M. E., Bouchard, C., Jetté, M., \& Laferrière, S. (2000). La violence familiale dans la vie des enfants du Québec 1999 [Family violence in the lives of Quebec children 1999]. Québec, QC: Institute de la Statistique du Québec.

Covell, K., \& Howe, R.B. (2001). The challenge of children's rights for Canada. Waterloo, ON: Wilfred Laurier Press. 
International Journal of Child, Youth and Family Studies (2017) 8(3-4): 127-153

Covell, K. \& Howe, R. B. (2009). Children, families and violence: Challenges to children's rights. London, UK: Jessica Kingsley.

Crandall, M., Chiu, B., \& Sheehan, K. (2006). Injury in the first year of life: Risk factors and solutions for high-risk families. Journal of Surgical Research, 133, 7-10. doi:10.1016/j.jss.2006.02.027

Crouch, J. L., \& Behl, L. E. (2001). Relationships among parental beliefs in corporal punishment, reported stress, and physical child abuse potential. Child Abuse \& Neglect, 25, 413-419. doi:10.1016/S0145-2134(00)00256-8

Deater-Deckard, K., Lansford, J., Dodge, K. A., Pettit, G. S., \& Bates, J. E. (2003). The development of attitudes about physical punishment: An 8-year longitudinal study. Journal of Family Psychology, 17, 351-360. doi:10.1037/0893-3200.17.3.351

Dobbs, T. A., Smith, A. B., \& Taylor, N. J. (2006). "No, we don’t get a say, children just suffer the consequences": Children talk about family discipline. International Journal of Children's Rights, 14, 137-156. doi:10.1163/157181806777922694

Durrant, J. E., \& Janson, S. (2005). Legal reform, corporal punishment and child abuse: The case of Sweden. International Review of Victimology, 12, 139-158. doi:10.1177/026975800501200203

Durrant, J. E., Rose-Krasnor, L., Broberg, A. (2003). Maternal beliefs about physical punishment in Sweden and Canada. Journal of Comparative Family Studies, 34, 586-604. doi:

Durrant, J. E., Sigvaldason, N., \& Bednar, L. (2008). What did the Canadian public learn from the Supreme Court decision on physical punishment? International Journal of Children's Rights, 16, 229-247. doi:10.1163/157181808X301818

Durrant, J. E., Trocmé, N., Fallon, B., Milne, C., Black, T., \& Knoke, D. (2006). Punitive violence against children in Canada. Technical Paper Series (\#HT09102001/001/SS). Ottawa, ON: Public Health Agency of Canada.

Federal Ministry for Family Affairs, Senior Citizens, Women and Youth, \& Federal Ministry of Justice. (2003). Violence in upbringing: An assessment after the introduction of the right to a non-violent upbringing. Berlin, Germany: Authors.

Fréchette, S., Zoratti, M., \& Romano, E. (2015). What is the link between corporal punishment and child physical abuse? Journal of Family Violence, 30, 135-148. doi:10.1007/s10896014-9663-9

Freeman, M., \& Saunders, B. (2014). Can we conquer child abuse if we don't outlaw physical chastisement of children? International Journal of Children's Rights, 22, 681-709. doi:10.1163/15718182-02204002 
International Journal of Child, Youth and Family Studies (2017) 8(3-4): 127-153

Gagné, M.-H., Tourigny, M., Joly, J., \& Pouliot-Lapointe, J. (2007). Predictors of adult attitudes toward corporal punishment of children. Journal of Interpersonal Violence, 22, 1285-1304. doi: $10.1177 / 0886260507304550$

Garbarino, J. (1977). The human ecology of child maltreatment: A conceptual model for research. Journal of Marriage and the Family, 39, 721-735. doi:10.2307/350477

Gelles, R. J., \& Straus, M. A. (1988). Intimate violence: The causes and consequences of abuse in the American family. New York, NY: Touchstone.

Gershoff, E. T. (2013). Spanking and child development: We know enough now to stop hitting our children. Child Development Perspectives, 7, 133-137. doi:10.1111/cdep.12038

Gershoff, E. T., \& Bitensky, S. H. (2007). The case against corporal punishment of children: Converging evidence from social science research and international human rights law and implications for U.S. public policy. Psychology, Public Policy, and Law, 13, 231-272. doi:10.1037/1076-8971.13.4.231

Gershoff, E. T., \& Grogan-Kaylor, A. (2016). Spanking and child outcomes: Old controversies and new meta-analyses. Journal of Family Psychology, 30, 453-469.

doi:10.1037/fam0000191

Gil, D. G. (1970). Violence against children: Physical child abuse in the United States. Cambridge, MA: Harvard University Press.

Gopaul-McNichol, S.-A. (1999). Ethnocultural perspectives on childrearing practices in the Caribbean. International Social Work, 42, 79-86. doi:10.1177/002087289904200108

Holden, G. W., Coleman, S. M., \& Schmidt, K. L. (1995). Why 3-year old children get spanked: Parent and child determinants as reported by college-educated mothers. Merrill-Palmer Quarterly, 41, 431-452. doi:10.1111/cdep.12038

Janson, S., Jernbro, C., \& Långberg, B. (2011). Kroppslig bestraffning och annan kränkning av barn i Sverige: En nationell kartläggning 2011 [Corporal punishment and other humiliating behavior towards children in Sweden: A national survey 2011]. Stockholm, Sweden: Stiftselsen Allmänna Barnhuset.

Jud, A., \& Trocmé, N. (2013). Physical abuse and physical punishment in Canada [Canadian Child Welfare Research Portal information sheet \#122E]. Montreal, QC: McGill University, Centre for Research on Children and Families.

Kadushin, A., \& Martin, J. A. (1981). Child abuse: An interactional event. New York, NY: Columbia University Press. 
International Journal of Child, Youth and Family Studies (2017) 8(3-4): 127-153

Kelder, L. R., McNamara, J. R., Carlson, B., \& Lynn, S. J. (1991). Perceptions of physical punishment: The relation to childhood and adolescent experiences. Journal of Interpersonal Violence, 6, 432-445. doi:10.1177/088626091006004003

Kempe, C. H., Silverman, F. N., \& Steele, B. F., Droegmueller, W., \& Silver, H. K. (1962). The battered child syndrome. Journal of the American Medical Association, 181, 17-24. doi:10.1001/jama.1962.03050270019004

Knutson, J. F., \& Selner, M. B. (1994). Punitive childhood experiences reported by young adults over a 10-year period. Child Abuse \& Neglect, 18, 155-166. doi:10.1016/0145$\underline{2134(94) 90117-1}$

Lansford, J. E., Godwin, J., Tirado, L. M. U., Zelli, A., Al-Hassan, S. M., Bacchini, D., ... Alampay, L. P. (2015). Individual, family, and culture level contributions to child physical abuse and neglect: A longitudinal study in nine countries. Development and Psychopathology, 27, 1417-1428. doi:10.1017/S095457941500084X

Lunkenheimer, E. S., Kittler, J. E., Olson, S. L., \& Kleinberg, F. (2006). The intergenerational transmission of physical punishment:Differing mechanisms in mothers' and fathers' endorsement? Journal of Family Violence, 21, 509-519. doi:10.1007/s10896-006-9050-2

Margolin, L. (1990). Child abuse by babysitters: An ecological-interactional interpretation. Journal of Family Violence, 5, 95-105. doi:10.1007/BF00978513

McGillivray, A. (2011a). 'He'll learn it on his body': Disciplining childhood in Canadian law. In M. D. A. Freeman (Ed.), Children's rights: Progress and perspectives: Essays from the International Journal of Children's Rights (pp. 311-365). Leiden, The Netherlands: Brill.

McGillivray, A. (2011b). Nowhere to stand: Correction by force in the Supreme Court of Canada. In S. Anand (Ed.), Children and the law: Essays in honour of Professor Nicholas Bala (pp. 57-76). Toronto, ON: Irwin Law.

McGillivray, A., \& Durrant, J. E. (2012). Child corporal punishment: Violence, rights and law. In R. Alaggia \& C. Vine (Eds.), Cruel but not unusual: Violence in Canadian families (pp. 91-118). Waterloo, ON: Wilfred Laurier Press.

McGillivray, A., \& Milne, C. (2011). Canada: The rocky road of repeal. In J. Durrant \& A. Smith (Eds.), Global pathways to abolishing physical punishment: Realizing children's rights (pp. 98-111). New York, NY: Routledge.

Miller, K. S., \& Knutson, J. F. (1997). Reports of severe physical punishment and exposure to animal cruelty by inmates convicted of felonies and by university students. Child Abuse \& Neglect, 2, 59-82. doi:10.1016/S0145-2134(96)00131-7 
International Journal of Child, Youth and Family Studies (2017) 8(3-4): 127-153

Murphy-Cowan, T., \& Stringer, M. (1999). Physical punishment and the parenting cycle: A survey of Northern Irish parents. Journal of Community \& Applied Social Psychology, 9, 61-71. doi:10.1002/(SICI)1099-1298(199901/02)9:1<61::AID-CASP502>3.0.CO;2-P

Orhon, F. S., Ulukol, B., Bilonger, B., \& Gulnar, S. B. (2006). Attitudes of Turkish parents, pediatric residents, and medical students toward child disciplinary practices. Child Abuse \& Neglect, 30, 1081-1092. doi:10.1016/j.chiabu.2006.04.004

Payne, M. A. (1989). Use and abuse of corporal punishment: A Caribbean view. Child Abuse \& Neglect, 13, 389-401. doi:10.1016/0145-2134(89)90079-3

Pinheiro, P. (2006). World report on violence against children. Geneva, Switzerland: United Nations Secretary-General's Study on Violence against Children.

Public Health Agency of Canada. (2010). Canadian incidence study of reported child abuse and neglect - 2008: Major findings. Ottawa, ON: Author.

Prescott, A., Bank, L., Reid, J. B., Knutson, J. F., Burraston, B. O., \& Eddy, J. M. (2000). The veridicality of punitive childhood experiences reported by adolescents and young adults. Child Abuse \& Neglect, 24, 411-423. doi:10.1016/S0145-2134(99)00153-2

Rausch, K., \& Knutson, J. F. (1991). The self-report of personal punitive childhood experiences and those of siblings. Child Abuse \& Neglect, 15, 29-36. doi:10.1016/0145-2134(91)90087-T

Roberts, M. W., \& Powers, S. W. (1990) Adjusting chair timeout enforcement procedures for oppositional children. Behavior Therapy, 21, 257-271. doi:10.1016/S0005-7894(05)80329-6

Rodriguez, C. M., \& Sutherland, D. (1999). Predictors of parents' physical disciplinary practices. Child Abuse \& Neglect, 23, 651-657. doi:10.1016/S0145-2134(99)00043-5

Russa, M. B., Rodriguez, C. M., \& Silvia, P. J. (2014). Frustration influences impact of history and disciplinary attitudes on physical discipline decision making. Aggressive Behavior, 40, 1-11. doi:10.1002/ab.21500

Saunders, B. J., \& Godard, C. (2008). Some Australian children's perceptions of physical punishment in childhood. Children \& Society, 22, 405-417. doi:10.1111/j.10990860.2007.00127.x

Smith, A. B., \& Durrant, J. E. (2011). Witnessing history and charting the future: Pathways to prohibition. In J. E. Durrant and A. B. Smith (Eds.), Global pathways to abolishing physical punishment: Realizing children's rights (pp. 323-338). New York, NY: Routledge.

Socolar, R. R., \& Stein, R. E. K. (1995). Spanking infants and toddlers: Maternal beliefs and practice. Pediatrics, 95,105-111.

Statistics Canada. (2015). Family violence in Canada: A statistical profile, 2013. Ottawa, ON: Canadian Centre for Justice Statistics. 
International Journal of Child, Youth and Family Studies (2017) 8(3-4): 127-153

Statistics Sweden. (1996). Spanking and other forms of physical punishment: A study of adults' and middle school students' opinions, experience, and knowledge. Demografiska Rapporter, 1.2. Stockholm, Sweden: Author.

Straus, M. A. (1994). Beating the devil out of them: Corporal punishment in American families. New York, NY: Lexington.

Taylor, C. A., Hamvas, L., \& Paris, R. (2011). Perceived instrumentality and normativeness of corporal punishment use among black mothers. Family Relations, 60, 60-72. doi:10.1111/j.1741-3729.2010.00633.x

Trocmé, N., Fallon, B., MacLaurin, B., Daciuk, J., Felstiner, C., Black, T., ... Cloutier, R. (2005). Canadian incidence study of reported child abuse and neglect-2003: Major findings [Report]. Ottawa, ON: Minister of Public Works and Government Services Canada.

Trocmé, N., MacLaurin, B., Fallon, B., Daciuk, J., Billingsley, D., Tourigny, M., ... McKenzie, B. (2001). Canadian incidence study of reported child abuse and neglect 1998 (CIS-1998): Final report. Ottawa, ON: Minister of Public Works and Government Services Canada.

Trocmé, N., Siddiqi, J., Fallon, B., MacLaurin, B., \& Sullivan, S. (2002). Ontario incidence study of reported child abuse and neglect 1993/1998 maltreatment rates [OIS series fact sheet \#1, May]. Toronto, ON: Centre of Excellence for Child Welfare.

Wang, M., \& Xing, X. (2014). Intergenerational transmission of parental corporal punishment in China: The moderating role of spouse's corporal punishment. Journal of Family Violence, 29, 119-128. doi:10.1007/s10896-013-9574-1

Watkinson, A. M. (1999). Education, student rights and the Charter. Saskatoon, SK: Purich Publishing.

Watkinson, A. M. (2006). Supreme Court of Canada stands behind corporal punishment — sort of .... International Social Work Journal, 49, 531-536. doi:10.1177/0020872806065329

Watkinson, A. M. (2009). Corporal punishment and education: Oh Canada! Spare us! In M. Manley-Casimir (Ed.), The courts, the Charter and the schools: The impact of the Charter of Rights and Freedoms on educational policy and practice (pp. 181-199). Toronto, ON: University of Toronto Press.

Woodward, L. J., \& Fergusson, D. M. (2002). Parent, child, and contextual predictors of childhood physical punishment. Infant \& Child Development, 11, 213-235. doi:10.1002/icd.252

Zolotor, A. J., Theodore, A. D., Chang, J. J., Berkoff, M. C., \& Runyan, D. K. (2008). Speak softly — and forget the stick. American Journal of Preventive Medicine, 35, 364-369. doi:10.1016/j.amepre.2008.06.031 